\title{
Evaluation of macrominerals concentrations in blood of lactating and dry Desi cows
}

\section{Evaluación de concentraciones de macrominerales en sangre de vacas Desi lactantes y secas}

\author{
Zafar Iqbal Khan, ${ }^{1}$ Ph.D, Alireza Bayat, ${ }^{2}$ Ph.D, Kafeel Ahmad, ${ }^{1}$ Ph.D, \\ Muhammad Sher, ${ }^{3}$ Ph.D, Muhammad Khalid Mukhtar, ${ }^{1}$ Ph.D, Zafar Hayat, ${ }^{4}$ Ph.D, \\ Vincenzo Tufarelli, ${ }^{5 *}$ Ph.D.
}

\begin{abstract}
${ }^{1}$ University of Sargodha, Department of Biological Sciences, Pakistan. ${ }^{2}$ Animal Production Research, MTT, FI 31600, Jokioinen, Finland. 'University of Sargodha, Department of Chemistry, Pakistan. ${ }^{4}$ University of Sargodha, Department of Animal Sciences, Pakistan. 'Eniversity of Bari 'Aldo Moro', Department of Emergency and Organ Transplantation, Section of Veterinary Science and Animal Production, Bari, Italy. *Correspondence: vincenzo.tufarelli@uniba.it
\end{abstract}

Received: October 2014; Accepted: March 2015.

\begin{abstract}
Objective. This study was conducted during winter season at rural livestock farm of district Sargodha, Pakistan, in order to define the macrominerals status in blood plasma of lactating and dry Desi breed cows. Material and methods. Twenty lactating and twenty dry cows were used and their blood plasma was analyzed for $\mathrm{Ca}, \mathrm{Mg}, \mathrm{Zn}, \mathrm{Cu}$ and Fe using atomic absorption spectrophotometer. Results. In lactating cows, the plasma Ca concentration was lower than dry cows $(6.8 \mathrm{vs} .7 .6 \mathrm{mg} / \mathrm{dl}, \mathrm{p}<0.001)$, while $\mathrm{Mg}$ concentration was similar between lactating and dry cows. Plasma Zn concentration in lactating cows was higher than dry cows $(0.78 \mathrm{vs} .0 .60 \mathrm{mg} / \mathrm{l}, \mathrm{p}<0.01)$ and it resulted lower than the normal range in both groups. Plasma Cu level in lactating cows was lower than dry cows $(0.56 \mathrm{vs} .0 .76 \mathrm{mg} / \mathrm{L}$, $\mathrm{p}<0.001)$ and it was lower than the normal range only in lactating cows. Lactating cows resulted in higher plasma Fe concentration compared to dry cows ( 3.8 versus $2.6 \mathrm{mg} / \mathrm{L} ; \mathrm{p}<0.01$ ). Conclusions. From our findings, it can be concluded that the observed minerals level meets the needs of ruminants and the plasma level of different minerals is affected by the physiological stages of cows.
\end{abstract}

Key words: Dry cow, lactating cow, minerals, plasma (Source: $C A B$ ).

\section{RESUMEN}

Objetivo. Este estudio se realizó durante la estación de invierno en la granja de ganado rural del distrito de Sargodha, Pakistán, con el fin de definir el estado de macrominerales en el plasma sanguíneo de vacas lactantes y secas de raza Desi. Materiales y métodos. Veinte vacas lactantes y veinte vacas secas fueron utilizadas y se analizó el plasma para el $\mathrm{Ca}, \mathrm{Mg}, \mathrm{Zn}, \mathrm{Cu}$ y Fe utilizando un espectrofotómetro de absorción atómica. Resultados. En las vacas lactantes, la concentración de Ca en plasma fue menor que en las vacas secas ( 6.8 frente a $7.6 \mathrm{mg} / \mathrm{dl}, \mathrm{p}<0.001$ ), mientras que la concentración de $\mathrm{Mg}$ fue similar entre las lactantes y las vacas secas. La concentración plasmática de $\mathrm{Zn}$ en las vacas lactantes fue mayor que en las vacas secas $(0.78$ frente a $0.60 \mathrm{mg} / \mathrm{L}, \mathrm{p}<0.01)$ y resultó inferior al rango normal en ambos grupos. Nivel de plasma de $\mathrm{Cu}$ en vacas lactantes fue inferior al de las vacas secas $(0.56$ vs a $0.76 \mathrm{mg} / \mathrm{L}, \mathrm{p}<0.001)$ y fue inferior al rango normal sólo en las vacas lactantes. Las vacas lactantes resultaron en mayor concentración de Fe plasmático en comparación con las vacas secas ( 3.8 frente a $2.6 \mathrm{mg} / \mathrm{l}, \mathrm{p}<0.01$ ). Conclusiones. A partir de los resultados, se puede concluir que el nivel de minerales observados satisface las necesidades de los rumiantes y el nivel plasmático de diferentes minerales se ve afectado por las etapas fisiológicas de las vacas.

Palabras clave: Plasma, minerales, vacas en lactación, vaca seca (Source: $C A B$ ). 


\section{INTRODUCTION}

Livestock needs the balanced and suitable levels of all the required nutrients for their animal health and production in any physiological stage (1). Minerals represent essential nutrients having a pronounced function in the life of organisms as their imbalances exert undesirable effects, especially in ruminants. Various microelements and some macro elements have been known to be very essential for livestock growth $(2,3)$. Microelements function as cofactors are involved in many structural molecules in living organisms $(2,4)$.

The elemental composition of body tissue fluids commonly reflects the dietary level of ruminants to a certain extent, depending on the animal tissue fluid and the mineral element in question. Chemical composition of animal tissue fluids can therefore be employed to assess the range of mineral elemental adequacies in ruminants. The blood plasma is an excellent indicator of minerals in animals, and also can be easily obtained from the animal without slaughtering procedures (2). Although some information is attainable on the normal mineral profile of Sahiwal cattle (5), however very little information is available on the mineral status of Desi cows. Therefore, the aim of this investigation is to evaluate the mineral status of lactating and dry cows comparatively. It is expected that the results will be useful for formulating the mineral mixtures to overcome the deficiency and toxicity of different minerals in this livestock species.

\section{MATERIALS AND METHODS}

Study site. Pakistan is mainly an agricultural country with an arid and semi-arid continental subtropical climate. It is located between 23 and $36^{\circ} \mathrm{N}$ latitude and 60 and $75^{\circ} \mathrm{E}$ longitude.

The present investigation was conducted on Desi breed cows reared in the district of Sargodha, at a rural livestock farm during the winter season of 2013. The district of Sargodha is located between $30^{\circ} 05^{\prime} \mathrm{N}$ longitude and $72^{\circ} 67^{\prime} \mathrm{E}$ latitude and its altitude is $180 \mathrm{~m}$ above sea level. Different improved pastures as feeding sites for animals are possessed by the livestock farm. The pastures were fertilized and irrigated with tubewell and canal water. The main forage species available to animals during the winter were Medicago sativa and Trifolium alexandrinum as major forages, and Cichorium intybus, Brassica compestris, and Avena sativa as minor forages. The pasture was the main source of feeding for dairy cattle during the research period.

\section{INTRODUCCIÓN}

El ganado necesita niveles balanceados y adecuados de todos los nutrientes que se requieren para su salud zoosanitaria y para la producción en cualquier etapa fisiológica (1). Los minerales representan nutrientes esenciales que tienen una función pronunciada en la vida de los organismos, ya que su desequilibrio ejerce efectos no deseados, específicamente en el caso de los rumiantes. Se han identificado varios microelementos y algunos macroelementos que son esenciales para el crecimiento del ganado $(2,3)$. Los microelementos funcionan como cofactores involucrados en varias moléculas estructurales de los organismos vivos $(2,4)$.

La composición elemental de los fluidos del tejido corporal normalmente refleja en cierta medida los niveles dietéticos de los rumiantes, dependiendo del fluido de tejido animal y del elemento mineral en cuestión. Por lo tanto, la composición química de los fluidos de tejido animal puede ser empleada para evaluar el qué tan adecuado es el nivel de minerales elementales en los rumiantes. El plasma sanguíneo es un excelente indicador de los minerales presentes en animales y a la vez puede obtenerse fácilmente sin necesidad de procedimientos de matanza (2). Aunque es posible acceder a cierta información del perfil mineral del ganado Sahiwal (5), hay muy poca información disponible acerca del estado de los minerales en las vacas Desi. Por lo tanto, el objetivo de esta investigación es evaluar comparativamente el estado de los minerales en vacas secas y lactantes. Se espera que los resultados sean útiles para formular las mezclas minerales que permitan superar la deficiencia y la toxicidad de distintos minerales en esta especie de ganado.

\section{MATERIALES Y MÉTODOS}

Lugar del estudio. Pakistán es un país principalmente agrícola con clima continental subtropical árido y semiárido. Está ubicado entre las latitudes 23 y $36^{\circ}$ norte y las longitudes 60 y $75^{\circ}$ este.

La presente investigación se realizó en vacas de raza Desi criadas en el distrito de Sargodha, en una finca ganadera rural durante el invierno de 2013. El distrito de Sargodha está ubicado entre las latitudes $30^{\circ} 05^{\prime}$ norte y $72^{\circ} 67^{\prime}$ este, con una altitud de $180 \mathrm{~m}$ sobre el nivel del mar. La finca ganadera posee distintos pastizales mejorados que sirven como lugar de alimentación para los animales. Los pastizales fueron fertilizados y regados con agua de pozos entubados y de canales. Las principales especies de forraje disponibles para los animales durante el invierno fueron Medicago sativa y Trifolium alexandrinum en mayor medida, 
Animals, sample collection and analysis. Twenty lactating and twenty dry Desi cows, with an average body weight of $315 \pm 37 \mathrm{~kg}$ (mean \pm standard deviation) and having 2-5 years old of age, were chosen and considered as experimental groups. About $20 \mathrm{ml}$ of blood from each animal was obtained in a clean sterilized glass test tube having heparin, as an anticoagulant, through jugular vein three times from October to December by one month interval at 11:00 am.

Blood was centrifuged $(3.000 \mathrm{rpm} \times 15-30 \mathrm{~min}$ ) and separated plasma was stored at $-20^{\circ} \mathrm{C}$ until analysis. Wet digestion using perchloric acid and nitric acid (6). The plasma minerals including calcium (Ca), magnesium $(\mathrm{Mg})$, copper $(\mathrm{Cu})$, zinc $(\mathrm{Zn})$ and iron (Fe) were determined using atomic absorption spectrophotometer (Perkin Elmer Corp.) according to the method of Akhtar et al (3).

Statistical analysis. Data were subjected to statistical analysis using the SPSS software and one-way analysis of variance (ANOVA) worked out. Statistical significance between the mean values was tested at $p<0.05$ level $(7,8)$.

\section{RESULTS}

Mean plasma concentrations for $\mathrm{Ca}, \mathrm{Mg}, \mathrm{Zn}, \mathrm{Cu}$ and $\mathrm{Fe}$ in lactating and dry cows are presented in table 1 . Plasma Ca concentration was significantly higher in dry compared to lactating cows (7.6 versus $6.8 \mathrm{mg} / \mathrm{dl} ; \mathrm{p}<0.001)$. Plasma $\mathrm{Mg}$ level was higher, but not significantly, in lactating compared to dry cows ( 1.60 versus $1.20 \mathrm{mg} /$ $\mathrm{dl} ; \mathrm{p}>0.05)$. Significant higher blood plasma Zn concentration was found in the lactating cows compared to the dry cows ( 0.78 versus 0.60 $\mathrm{mg} / \mathrm{l} ; \mathrm{p}<0.01)$. The Cu concentration of plasma was significantly lower in lactating compared to dry cows $(0.56$ versus $0.76 \mathrm{mg} / \mathrm{l} ; \mathrm{p}<0.001)$. The

Table 1. Mineral plasma concentrations of lactating and dry Desi cows.

\begin{tabular}{ccccc}
\hline Mineral & $\begin{array}{c}\text { Critical } \\
\text { value }^{1}\end{array}$ & $\begin{array}{c}\text { Lactating } \\
\text { cows }\end{array}$ & Dry cows & Significance $^{2}$ \\
\hline $\mathrm{Ca}, \mathrm{mg} / \mathrm{dl}$ & 8.00 & $6.8 \pm 0.15^{3}$ & $7.6 \pm 0.09$ & $* * *$ \\
$\mathrm{Mg}, \mathrm{mg} / \mathrm{dl}$ & 2.00 & $1.6 \pm 0.04$ & $1.2 \pm 0.03$ & $\mathrm{NS}$ \\
$\mathrm{Zn}, \mathrm{mg} / \mathrm{L}$ & 0.80 & $0.78 \pm 0.08$ & $0.60 \pm 0.05$ & $* *$ \\
$\mathrm{Cu}, \mathrm{mg} / \mathrm{L}$ & 0.65 & $0.56 \pm 0.07$ & $0.76 \pm 0.04$ & $* * *$ \\
$\mathrm{Fe}, \mathrm{mg} / \mathrm{L}$ & 1.10 & $3.8 \pm 0.03$ & $2.6 \pm 0.10$ & $* *$ \\
\hline
\end{tabular}

${ }_{1}^{1}$ According to McDowell and Arthington (13) and McDowell (16);

$2 * *, \mathrm{p}<0.01$

$* * *, \mathrm{p}<0.001$

NS, not significant ;

${ }^{3}$ mean \pm standard error. y en menor medida Cichorium intybus, Brassica compestris y Avena sativa. Los pastizales fueron la principal fuente de alimentación para el ganado lechero durante el periodo de investigación.

Animales, recolección de muestras y análisis. Se eligieron veinte vacas Desi lactantes y veinte secas, con un peso corporal promedio de $315 \pm 37 \mathrm{~kg}$ (media \pm desviación estándar) y una edad de $2-5$ años, que fueron consideradas como grupos experimentales. Se obtuvieron $20 \mathrm{ml}$ de sangre de cada animal en un tubo de ensayo de vidrio limpio y esterilizado, con heparina como anticoagulante, extraídos de la yugular tres veces de octubre a diciembre a intervalos de un mes a las 11:00 am.

La sangre se centrifugó (3.000 rpm $\times 15-30 \mathrm{~min}$ ) y el plasma separado se almacenó a una temperatura de $-20^{\circ} \mathrm{C}$ hasta ser analizado. Luego se hizo una digestión húmeda utilizando ácido perclórico y ácido nítrico (6). Se determinaron los materiales del plasma, incluyendo calcio $(\mathrm{Ca})$, magnesio $(\mathrm{Mg})$, cobre $(\mathrm{Cu})$, zinc $(\mathrm{Zn})$ y hierro $(\mathrm{Fe})$, utilizando un espectrómetro de absorción atómica (Perkin Elmer Corp.) según el método de Akhatar et al (3).

Análisis estadístico. Los datos fueron sometidos a un análisis estadístico utilizando software SPSS y se realizó un análisis de varianza en un solo sentido (ANOVA). La prueba de significación estadística entre los valores de medios se hizo a un nivel de $\mathrm{p}<0.05(7,8)$.

\section{RESULTADOS}

La concentración media de $\mathrm{Ca}, \mathrm{Mg}, \mathrm{Zn}, \mathrm{Cu}$ y Fe en plasma de vacas lactantes y secas se relaciona en la tabla 1. La concentración de Ca en plasma fue significativamente mayor en vacas secas en comparación con vacas lactantes ( 7.6 frente a $6.8 \mathrm{mg} / \mathrm{dl} ; \mathrm{p}<0.001)$. La concentración del nivel de $\mathrm{Mg}$ en plasma fue mayor, pero no de manera significativa, en vacas lactantes en comparación con vacas secas ( 1.60 frente a $1.20 \mathrm{mg} / \mathrm{dl} ; \mathrm{p}>0.05$ ). Se encontró una concentración en plasma de $\mathrm{Zn}$ significativamente mayor en las vacas lactantes en comparación con las vacas secas ( 0.78 frente a 0.60 $\mathrm{mg} / \mathrm{l} ; \mathrm{p}<0.01)$. La concentración de Cu en plasma fue significativamente menor en vacas lactantes en comparación con vacas secas $(0.56$ frente a 0.76 $\mathrm{mg} / \mathrm{l} ; \mathrm{p}<0.001)$. La concentración de Fe en plasma fue significativamente mayor en vacas lactantes en comparación con vacas secas (3.8 frente a 2.6 $\mathrm{mg} / \mathrm{l} ; \mathrm{p}<0.01)$.

\section{DISCUSIóN}

Otros Autores $(5,9)$ ya han reportado diferencias significativas en las concentraciones de $\mathrm{Ca}$ en plasma en las distintas etapas fisiológicas de las 
Fe concentration in blood plasma was significantly higher in lactating cows compared to dry cows (3.8 versus $2.6 \mathrm{mg} / \mathrm{l} ; \mathrm{p}<0.01$ ).

\section{DISCUSSION}

Significant differences in plasma $\mathrm{Ca}$ concentrations in cows in different physiological stages, similarly to our results, have been previously reported by other Authors $(5,9)$. In the present investigation, the low plasma Ca concentrations in lactating animals might be due to the physiological status of the animals; since blood Ca concentration is under the control of hormones, such as calcitonin and parathormone, acting on the kidneys, intestines and bones, and in dry cows, the blood levels of some vitamins which are under the control of these hormones increasing with the beginning of lactation (10). When ruminants start the lactation period, a reduction in plasma $\mathrm{Ca}$ concentration takes place due to high $\mathrm{Ca}$ requirements for milk production, and then $\mathrm{Ca}$ level starts to increase due to decreasing milk yield $(11,12)$.

In both dry and lactating groups, the plasma Mg concentrations were lower than the suggested value of $2 \mathrm{mg} / \mathrm{dl}$ for ruminants as described by Xin et al (13). Low plasma Mg concentration would be expected due to low $\mathrm{Mg}$ concentration in the forage and the mineral supplement consumed. The findings of the present investigation are also consistent with those reported by Khan et al (14) who reported similar low $\mathrm{Mg}$ concentration in the blood plasma of cattle and buffalo indicating the deficiency of this element. The most plausible reasons for low plasma $\mathrm{Mg}$ concentration might be the low absorption capacity of $\mathrm{Mg}$ in the gastrointestinal tract of animals (15) and the low $\mathrm{Mg}$ concentration in forage and mineral supplement.

Plasma Zn concentrations of cows in both physiological stages were below the normal range of $0.80 \mathrm{mg} / \mathrm{L}$ suggested by McDowell (16). However, no animal in both groups exhibited clinical signs of $\mathrm{Zn}$ deficiency such as rough skin with lesions. Other elements are involved in $\mathrm{Zn}$ metabolism in non ruminants, although in ruminants no such interactions with other elements have been yet reported $(16,17)$. It has also been reported that when $\mathrm{Zn}$ is bound to cell wall constituents, its bioavailability might reduce in livestock (18). Therefore, low $\mathrm{Zn}$ availability in animals in the present investigation might be due to such factors, hindering its availability. However, results of the current study are in agreement with the findings of other trials (19-21).

The $\mathrm{Cu}$ concentration in plasma of lactating cows was lower than the critical concentration vacas. En la presente investigación, las bajas concentraciones de Ca en animales lactantes puede deberse al estado fisiológico de los animales; dado que la concentración de Ca en sangre está bajo el control de las hormonas, tales como la calcitonina y la paratirina, que actúan sobre los riñones, intestinos y huesos, y en vacas secas, los niveles en sangre de algunas vitaminas que están controladas aumentan con el inicio de la lactancia (10). Cuando los rumiantes inician el periodo de lactancia, ocurre una reducción en la concentración de Ca en plasma debida a los altas exigencias de Ca para producir leche; posteriormente, el nivel de Ca empieza a aumentar conforme disminuye la producción de leche $(11,12)$.

Tanto en los grupos secos como en los lactantes, las concentraciones de $\mathrm{Mg}$ en plasma fueron menores al valor de $2 \mathrm{mg} / \mathrm{dl}$ sugerido para rumiantes según Xin et al (13). Se podría esperar una baja concentración de $\mathrm{Mg}$ en plasma debido a la baja concentración de $\mathrm{Mg}$ en el forraje y en el suplemento mineral consumidos. Los hallazgos de la presente investigación también son consistentes con los hallazgos reportados por Khan et al (14), quien reportó una baja concentración de $\mathrm{Mg}$ en el plasma sanguíneo de vacunos y búfalos similar, indicando la deficiencia de este elemento. Las razones más plausibles para explicar la baja concentración de $\mathrm{Mg}$ en plasma pueden ser la baja capacidad de absorción de $\mathrm{Mg}$ en el tracto gastrointestinal de los animales (15) y la baja concentración de $\mathrm{Mg}$ en el forraje y en el suplemento mineral.

Las concentraciones de $\mathrm{Zn}$ en las vacas de ambos estados fisiológicos estuvieron por debajo del rango normal de $0.80 \mathrm{mg} / \mathrm{L}$ sugerido por McDowell (16). Sin embargo, en ambos grupos ningún animal presentó signos clínicos de deficiencia de $\mathrm{Zn}$ tales como una textura de piel áspera con lesiones. En no rumiantes, hay otros elementos involucrados en la metabolización de $\mathrm{Zn}$, aunque en rumiantes no se han reportado aún interacciones tales con otros elementos $(16,17)$. También se ha reportado que cuando el $\mathrm{Zn}$ está ligado a los componentes de la pared celular, su biodisponibilidad se puede ver reducida en el ganado (18). Por lo tanto, la baja disponibilidad de $\mathrm{Zn}$ en los animales que se observó en la presente investigación puede ser debida a dichos factores, los cuales dificultan su disponibilidad.

Las concentraciones de $\mathrm{Cu}$ en vacas lactantes estuvieron por debajo de la concentración crítica de $0.65 \mathrm{mg} / \mathrm{L}$ sugerida por McDowell (16). Sin embargo, en el caso de vacas secas, el mayor nivel en la concentración de $\mathrm{Cu}$ comparado con el valor crítico sugiere que estos animales sufren de deficiencia de $\mathrm{Cu}$. Investigadores en Paquistán $(5,21)$, Colombia (22) y Nicaragua ya han reportado 
of $0.65 \mathrm{mg} / \mathrm{L}$ suggested by McDowell (16). However, in dry animals, the higher plasma $\mathrm{Cu}$ concentration compared to the critical value suggests that these animals do suffer from $\mathrm{Cu}$ deficiency. Similar differences in plasma $\mathrm{Cu}$ concentration have already been reported between different physiological groups of ruminants by researchers in Pakistan $(5,21)$, Colombia (22) and Nicaragua (23). These differences may be due to difference in geographical areas because of the blood mineral concentrations in animals have been reported to be differ from area to area (24). Contrary to our findings, Asif et al (5) reported significant lower $\mathrm{Cu}$ in plasma of cattle; however, the reason is still unclear.

The Fe plasma concentrations were sufficiently higher than the critical value of $1.10 \mathrm{mg} / \mathrm{L}$ suggested by McDowell (16). It has been reported that Fe deficiency is not a relevant problem in ruminant species and it only occurs when there is some loss of blood (15). Plasma Fe levels similar to the values obtained in our investigation have previously been reported for various classes of animals $(22,25)$. Availability of $\mathrm{Fe}$ in blood plasma is dependent on many factors; for instance, in some cases, high concentrations of phosphorus and phytate in the diet may reduce its absorption due to formation of insoluble complexes in the intestinal tracts of animals (17). In fact, Fe deficiency is not commonly widespread for grazing ruminants due to high concentrations of $\mathrm{Fe}$ in pasture as well as contamination of forages by soil particles and both these factors contribute much to the Fe requirements of animals (12).

The Fe deficiency becomes a problem when livestock are kept on low Fe content forages, and supplementation of this element may reduce weight losses in lactating animals and cause very rapid weight compensation in suckling animals (12). The Fe deficiency has been reported in some regions of the world at a time when ruminants grazed forage plants grow on sandy soils and have heavy insects or parasite infestation, then Fe supplementation has been useful for the suffering animals. The blood levels, as well as the condition of the ruminants have been improved under supplementation regime $(12,26)$. It has also been investigated that Fe supplementation shows no response in older animals consuming ordinary diets. However, Fe deficiency exists and in some cases, its supplementation exhibit marked improvement in the reproduction potential of the ruminants (10). In our investigation, the animals showed no Fe deficiency but it is possible that its supplementation would encourage reproduction capacity of the livestock grazing therein as Fe levels in blood plasma was lower than the suggested level. diferencias similares en la concentración de $\mathrm{Cu}$ en plasma entre distintos grupos fisiológicos de rumiantes. Dichas diferencias pueden deberse a las diferencias de las zonas geográficas, ya se ha reportado que las concentraciones de minerales en sangre de los animales difieren de una zona a la otra (24). A diferencia de nuestros hallazgos, Asif et al (5) reportó un nivel de Cu en plasma significativamente menor en el ganado; sin embrago, la razón aún no es clara.

Las concentraciones de $\mathrm{Fe}$ en plasma fueron suficientemente mayores al valor crítico de $1.10 \mathrm{mg} / \mathrm{L}$ sugerido por McDowell (16). Se ha reportado que la deficiencia de Fe no es un problema pertinente en las especies rumiantes y que ocurre únicamente cuando hay una pérdida de sangre (15). Para varias clases de animales, niveles de Fe en plasma similares a los valores obtenidos en nuestra investigación ya han sido reportados $(22,25)$. La disponibilidad de Fe en plasma depende de múltiples factores; por ejemplo, en algunos casos las altas concentraciones de fósforo y fitato en la dieta pueden reducir su absorción debido a la formación de complejos insolubles en el tracto intestinal de los animales (17). De hecho, la deficiencia de Fe comúnmente no se ve extendida en rumiantes de pastoreo debido a las altas concentraciones de $\mathrm{Fe}$ en los pastos, como también por la contaminación de partículas de tierra en los forrajes. Ambos factores contribuyen en gran medida a satisfacer los requerimientos de $\mathrm{Fe}$ en animales (12).

La deficiencia de Fe se vuelve problemática cuando el ganado se mantiene con forrajes de baja concentración de $\mathrm{Fe}$, en donde el suplemento de este elemento puede reducir la pérdida de peso en animales lactantes y puede causar una muy rápida compensación en el aumento de peso de los animales amamantados (12). Se ha reportado una deficiencia de $\mathrm{Fe}$ en algunas regiones del mundo cuando los rumiantes se alimentan de forraje proveniente de plantas que crecen en suelos arenosos y que están altamente infestadas con insectos o parásitos, en donde el suplemento de de Fe ha sido útil para los animales afectados. Tanto los niveles en sangre como la condición de los rumiantes han mejorado bajo el régimen de suplemento $(12,26)$. También se ha investigado que el suplemento de Fe no demuestra respuesta alguna en animales mayores que consumen dietas normales. Sin embargo, la deficiencia de Fe existe y en algunos casos la administración de suplementos ha demostrado una mejoría notoria en el potencial de reproducción de los rumiantes (10). En nuestra investigación, los animales no presentaron una deficiencia de $\mathrm{Fe}$, aunque es posible que el aporte de suplementos hubiera podido favorecer la capacidad de reproducción del ganado que allí pastaba, ya que los niveles de Fe en el plasma sanguíneo fueron menores al nivel sugerido. 
The plasma concentrations of elements were not only different in animals with different physiological stages (i.e., lactating vs. dry cows), but were also different compared to the animals in other areas and zones, indicating the area effect. It is possible that forage plants grown in pastures grazed by animals may have lower mineral element levels, at least for some minerals, due to leaching soil minerals by water and this deficiency is shown in the plasma minerals profile of ruminants reared in these areas. It has already been reported the mineral profiles of plants vary with the soil chemistry and also by the climatic factors such as temperature, precipitation and drainage of the particular region $(2,13)$.

In conclusion the results of this trial indicated that plasma $\mathrm{Ca}, \mathrm{Mg}, \mathrm{Zn}, \mathrm{Cu}$ and $\mathrm{Fe}$ concentrations are influenced by physiological stage in dairy cows. In fact, the plasma $\mathrm{Ca}$ and $\mathrm{Cu}$ concentrations were higher whereas plasma $\mathrm{Mg}, \mathrm{Zn}$ and Fe levels were lower in dry cows compared to lactating cows. Therefore, our results can be considered useful for formulating the mineral mixtures to overcome the deficiency and toxicity of different minerals in cows.
Las concentraciones en plasma de los elementos fueron distintos no solo en animales que estaban en distintas etapas fisiológicas (es decir, vacas lactantes frente a vacas secas), sino que también fueron distintos entre animales de distintas áreas y zonas, lo cual indica que existe un efecto de área. Es posible que las plantas de las cuales se compone el forraje que crecen en pastizales en donde pastan los animales tengan contenidos menores de los elementos minerales, al menos en el caso de algunos minerales, debido a la lixiviación de los minerales en el suelo por acción del agua, deficiencia que se evidencia en el perfil de minerales en plasma de los rumiantes criados en estas zonas. Ya ha sido reportado que los perfiles de minerales de las plantas varían con la química del suelo, como también por factores climáticos particulares de esta región tales como temperatura, precipitación y drenaje $(2,13)$.

En conclusión, los resultados de este estudio indicaron que las concentraciones en plasma de $\mathrm{Ca}, \mathrm{Mg}, \mathrm{Zn}, \mathrm{Cu}$ y Fe se ven influenciadas por la etapa fisiológica de las vacas. De hecho, las concentraciones en plasma de Ca y Cu fueron mayores, mientras que los niveles de $\mathrm{Mg}$, Zn y Fe fueron menores en vacas secas comparadas con vacas lactantes. Por lo tanto, nuestros resultados pueden considerarse útiles para formular las mezclas de minerales para superar la deficiencia y la toxicidad de los distintos minerales en las vacas.

\section{REFERENCES}

1. Barakat NA, Laudadio V, Cazzato E, Tufarelli V. Potential contribution of retama raetam (Forssk.) Webb \& Berthel as a forage shrub in Sinai, Egypt. Arid Land Res Manag 2013; 27(3):257-271.

2. Akhtar MS, Farooq AA, Mushtaq M Serum concentrations of copper, iron, zinc and selenium in cyclic and anoestrus Nili-Ravi Buffaloes kept under farm conditions. Pak Vet J 2009; 29(1):47-48.

3. Tufarelli V, Laudadio V. Dietary supplementation with selenium and vitamin $\mathrm{E}$ improves milk yield, composition and rheological properties of dairy Jonica goats. J Dairy Res 2011; 78(02):144-148.

4. Tufarelli V, Khan RU, Laudadio V. Effect on milking performance of vitamin-trace element supplements to early lactation Italian Brown cows grazing ryegrass (Lolium multiflorum) pasture. Asian-Australas J Anim Sci 2011; 24(9):1227-1232.

5. Asif A, Rahman Z, Asif M, Haq IU, Javed I. Trace element and electrolyte concentrations in different physiological states of Sahiwal cattle. J Islam Acad Sci 1996; 9(4):125-128.
6. Khan N, Jeong IS, Hwang IM, Kim JS, Choi $\mathrm{SH}$, Nho EY, Kim KS. Method validation for simultaneous determination of chromium, molybdenum and selenium in infant formulas by ICP-OES and ICP-MS. Food Chem 2013; 141(4):3566-3570.

7. SAS SAS System for Linear Models. North Carolina: SAS Institute Inc., Cary, 2004.

8. Steel RGD, Torrie JH. Principle and Procedure of Statistics; A Biometrical Approach. $2^{\text {nd }}$ edn. New York: Mc. Graw Hill Books Co, USA, 1986.

9. Machado SC, McManus CM, Stumpf MT, Fischer V. Concentrate: forage ratio in the diet of dairy cows does not alter milk physical attributes. Trop Anim Health Prod 2014; 46(5):855-859.

10. Caldari-Torres C, Lock AL, Staples CR, Badinga L. Performance, metabolic, and endocrine responses of periparturient Holstein cows fed 3 sources of fat. J Dairy Sci 2011; 94(3):1500-1510. 
11. Jawor PE, Huzzey JM, LeBlanc SJ, von Keyserlingk MAG. Associations of subclinical hypocalcemia at calving with milk yield, and feeding, drinking, and standing behaviors around parturition in Holstein cows. J Dairy Sci 2012; 95(3):240-1248.

12. Felix TL, Zerby HN, Moeller SJ, Loerch SC. Effects of increasing dried distillers grains with solubles on performance, carcass characteristics, and digestibility of feedlot lambs. J Anim Sci 2012; 90(4):1356-1363.

13. Xin GS, Long RJ, Guo XS, Irvine J, Ding LM, Ding LL, Shang ZH. Blood mineral status of grazing Tibetan sheep in the Northeast of the Qinghai-Tibetan Plateau. Livest Sci 2011; 136(2):102-107.

14. Khan ZI, Ahmad K, Ashraf M, Raza N, Sher M. Assessment of molybdenum status in soil and forage for ruminant production under semiarid environmental conditions in Sargodha, Pakistan. Biol Trace Elem Res $2011 ; 142(3): 465-470$.

15. Shisia KS, Ngure V, Nyambaka $H$, Oduor FDO. Effect of $\mathrm{pH}$ and forage species on mineral concentrations in cattle breeds in major grazing areas of Uasin Gishu county, Kenya. Int J Curr Microbiol Appl Sci 2013; 2(12): 247-254.

16. McDowell, L.R.: Nutrition of Grazing Ruminants in Warm Climates. San Diego: Academic Press, 1985.

17. Dias RS, López $S$, Montanholi YR, Smith B, Haas LS, Miller SP, France J. A metaanalysis of the effects of dietary copper, molybdenum, and sulfur on plasma and liver copper, weight gain, and feed conversion in growing-finishing cattle. J Anim Sci 2013; 91(12):5714-5723.

18. Cazzato E, Laudadio V, Stellacci AM, Ceci E, Tufarelli V. Influence of sulphur application on protein quality, fatty acid composition and nitrogen fixation of white lupin (Lupinus albus L.). Eur Food Res Technol 2012; 235(5):963-969.

19. Shamsoldini M, Salehi M, Mirzaei F. Seasonal evaluation of the amount of $z n$ in serum of fluffy goats. J Anim Sci Adv 2012; 2(3):261267.
20. Hayshida M, Edgar AO, Emilo MC, Libertado CC, Fujihara T. Effect of concentrate supplementation on blood mineral concentration of growing upgraded Philippine goats. Anim Sci J 2004; 75(2):139-145.

21. Khan ZI, Hussain A, Ashraf M, McDowell LR, Ermidou-Pollet $S$. Transfer of zinc from soil and forage to goats grazing in a semi-arid region of Pakistan: Influence of seasons and the period of sampling. Trace Elem Electrol 2009; 26(2):31-38.

22. Pastrana R, McDowell LR, Conrad HJ, Wilkinson NS. Mineral status of sheep in the Pramo region of Colombia. II. Trace minerals. Small Rumin Res 1991; 5(1):2324.

23. Tufarelli V, Petrera F, Khan RU, Laudadio V. Vitamin and trace element supplementation in grazing dairy ewe during the dry season: effect on milk yield, composition, and clotting aptitude. Trop Anim Health Prod 2011, 43(5):955-960.

24. Akhtar MS, Lodhi LA, Ahmad I, Qureshi ZI, Muhammad G. Serum concentrations of calcium, phosphorus and magnesium in pregnant Nili-ravi buffaloes with or without vaginal prolapse in irrigated and rain fed areas of Punjab, Pakistan. Pak Vet J 2008; 28(2):107-110.

25. Khan ZI, Hussain A, Ashraf M, McDowell LR. Assessment and comparison of blood plasma mineral concentrations of different classes of grazing sheep. Trace Elem Electrol 2008; 25(1):7-13.

26. Davis PA, McDowell LR, VanAlstyne R, Marshall TT, Buergelt CD, Weldon RN, Wilkinson NS. Effects of form of parenteral or dietary selenium supplementation on body weight and blood liver and milk concentrations in beef cows. Prof Anim Sci 2008; 24(1):52-55. 